The Geneva Papers on Risk and Insurance, 22 (No. 85, October 1997), 515-522

\title{
How to Expand the Limits of Insurability*
}

\author{
by Walter T. Karten**
}

\section{Introduction}

The contribution of insurance to a sustainable development of our world in light of society's varied existential risks is a question which bears particular relevance. This paper shall throw some light on the limits of insurability, and so first take a brief look at insurance's well known positive effects.

The topic here is marketable insurance, which is sold in a market environment of workable competition, in other words is the result of supply and demand. Insurers are organized either with profits in mind or as mutuals. Social insurance systems fulfill the functions of insurance only at a rudimentary level; they lead to systematic wealth redistribution (subsidies) in addition to some risk spreading. Such redistributions require a fundamental political reason as do all interventions in free insurance markets; state intervention has its place only, if markets fail in terms of broader goals, which enjoy precedence.

Insurance's utility for risk averse individuals due to its capacity to reduce risk and the resulting increase in general welfare for society's economic agents as a whole are well known. Above and beyond this basic effect, one must however emphasize insurance's fundamental contribution to the economy. This contribution lies in providing an incentive, which promotes increased productivity. ${ }^{1}$ If liability insurance is as important as electricity 2 for many companies, then the absence of insurance's protection inhibits and discourages Raths.

* Presented at the 11th M.O.R.E-Seminar, Oslo 2/26,1996, translated from German by Herbert J.

** University of Hamburg, Germany

${ }^{1}$ See Sinn (1988).

2 Governor's Advisory Commission on Liability Insurance, State of New York, Insuring our Future 5, 1986, cit. in Abraham (1980), p. 948. 
entrepreneurial activity and improvement of the means of production. An especially poignant problem arises, when strict liability coincides with incomplete coverage, as is the case with environmental damages. Such situations can drive companies to relocate to countries with less rigorous environmental protection and liability standards, which certainly can not lie in the global economy's best interest.

The accompanying - on occasion significant - negative incentives of moral hazard should not be overlooked despite insurance's positive allocation and preventive effects. To assign risks' costs to economic agents according to their cause, compatible legal liability is primarily needed; insurance normally weakens the preventive effect of such legislation. Then again, deductibles or coinsurance and risk adjusted premiums can counteract this tendency.

Basically insurance can only reduce individual risks. It does not address the general uncertainty of the economy's development as a consequence of business cycles and grave structural changes or as a consequence of abrupt scarcity of energy or other resources. These types of risks require an appropriate risk policy for the economy as a whole - first and foremost by creating elasticity and by avoiding one-sided dependency. But the border between those general and insurable individual risks is somewhat ambiguous.

The variety and dimension of the risks, which people face, extend further than the capability to insure them. It is astonishing, what the insurance industry is considered capable of, how naively such conclusions are reached, and what demands are placed on the industry in certain cases regardless of its notoriously poor image. The impact of marketable insurance is restricted and always secondary in nature; it follows risk. Marketable insurance is basically not well-suited as a political instrument, for example to impose government institutional or legal policy goals, and cannot replace policy initiatives, such as environmental protection. Its object is rather to supplement these initiatives.

\section{Criteria of insurability}

Insurability knows no basic formula. When it's stated, that catastrophe risks or general entrepreneurial risk cannot be insured, the problem is simply transferred to the definition of these concepts. The pragmatic observation, that everything, for which insurance coverage is offered somewhere in the world, (and exactly that) is insurable, points us in the right direction: one must find an insurer, who dares to accept the risk. Pinpointing insurability in this manner is certainly correct from any viewpoint, but in the end doesn't help much; one obtains nothing more than a momentary picture. In reality, the limits of insurability change constantly. Beyond that, this observation doesn't provide a basis, to determine those factors, which define the limits of insurability.

Insuring risks is not a matter of general laws, rather a problem of deciding. No objective attributes exist, which unambiguously define a certain risk as "insurable" or "not insurable." The decision's determinants shall be quickly cited here. Arguments for and explanations of the following catalog can be found in previous expositions of the topic. ${ }^{3}$

${ }^{3}$ See Karten (1972), (1988), (1993), (1996). 
Risks are insurable, if an insurer and an insurance demander exist, who come to an agreement about product and price regarding the insurance coverage; risks are insurable only in this situation. The product is certainly more comprehensive than the purely technical conditions, which determine which events are insured and which payments correspond with each insured event, that is the stochastic variable of compensations which determines the probability distribution of insured losses. For example, the insurance product also encompasses various service components.

All the same, what matters as far as insurability is concerned is the technical side, namely the potential payments and their probabilities. As a result, insurability can be reduced to the technical difficulties of the definition of insurance products and finally of the premiums. The observation, that the capacity offered in national and global insurance markets depends notably on premium levels, supports this conclusion.

Then again, this entirely correct recognition of the fact, that the level of premiums alone determines insurability in the end, doesn't answer the question we have posed, if we wish to know, why insurers don't consider themselves capable of covering certain risks at a given level of premiums and also what aspect(s) of these risks pose difficulties. From the insurer's viewpoint, every insurance decision depends on the following subjective elements:

- the insurer's goals

- his assessment of the risk

- his degree of risk aversion

- his capacity.

The final point depends further on the structure of his risk situation, that is the aggregated risk and the premium level of his collective, his level of security reserves (equity), and the management tools open to him (especially the reinsurance capacity available to him). The first and most immediate approach to extending the limits of insurability therefore lies in improving these parameters, which determine the insurer's capacity.

If, however, one seeks the attributes, which decide in the final instance, whether a certain risk finds coverage or not, then one must look no further than the composition of the risk's stochastic variable, and this can be inspected with the assistance of five wellknown criteria of varying relevance. We can identify these criteria, which a risk must fulfill to be insurable: Insured risks, i.e. the events and losses, have to be:

- random - an essential

- unambiguous - a solvable problem?

- estimable - an honest misunderstanding

- independent - an impending overcharge

- of appropriate size - a matter of capacity

Even with these criteria, it's not possible to define enduring limits of insurability according to a risk's characteristics. These limits, nonetheless, can be expanded within the grey area between clearly and not clearly insurable risks with the aid of well-targeted measures. Of especial importance is the realization, that these criteria don't constitute 
"either-or" conditions, rather they all will be violated to some extent in real-life insurance collectives.

The criterium of randomness requires, that the insured events and their consequences in terms of damages are uncertain in advance and can not be influenced by the insured's will. As apparent as it would seem, that willingly induced losses can not be insured suicide is nevertheless insured in life insurance - insurers never succeed anyway in creating completely airtight insurance policies, with purely random events and compensations (e.g. by excluding damages incurred with intent or gross negligence) as long as asymmetric information exists. Asymmetric information leads to adverse selection and to moral hazard, if the risk depends on the insured's behavior. A grave case of so-called "external moral hazard" exists, if for example the courts feel prompted by the existence of insurance coverage to generously interpret the insurer's liability. This phenomenon most certainly plays a significant role in the US-American legal system. In this case, insurability is simultaneously restricted by an additional dimension, namely the criterion, that the coverage agreed to must be unambiguous. Such effects can not be completely avoided, however to a certain degree they can be tolerated for the desired coverage. All the same, the prerequisite of random insured events is essential.

The criterion, that a risk must be unambiguous, requires, that the insured events and the assigned compensations are defined in such a manner, that the consequences of the relevant events' onset can be objectively deduced (that is in an intersubjectively consistent fashion) from the given facts. It is not only an imperative of legal continuity, rather unambiguously determining the maximum insured exposure bears central relevance to our concern of insurability. One would expect this to be a simple problem of the insurance policy's legal wording, however the tendency toward so called "judge made insurance" 4 demonstrates, that courts often expand the intended coverage. In an attempt to protect the consumer a policy's wording will sometimes be construed in a manner, which neither party originally conceived of. Actions of this type destabilize insurance's function to a large extent, because it catapults the insurer into utterly unpredictable uncertainty. But "it only becomes really problematical when the rules of the game are changed halfway through the match". 5

In the insurance business world, it is most often argued, that a risk can not be insured, because it is not estimable. What is meant by this is often unclear, yet can be rendered more precisely as the degree of information about the risk, that is about the possible losses and their probabilities. Reality shows, however, that even purely subjective probabilities provide a sufficient basis for insurance coverage in the face of virtually non-existent information, (e.g. when insuring the first offshore drilling derrick) if the product has been unambiguously defined. Most often, the other criteria comprise the reason to forego insurance. For this very reason the ability to estimate a given risk can be described as an "honest misunderstanding"6. Yet arguing that a risk can't be estimated underscores precisely the subjective nature of the decision.

\footnotetext{
${ }^{4}$ See Abraham (1980), p. 960.

${ }^{5}$ Faure (1995), p. 455, who recently to a large extend argued along the same lines.

${ }^{6}$ Karten (1988), p. 350.
} 
The criteria, that a risk must be independent and of appropriate size, are closely related. One limit of insurability certainly exists, if the losses from a single event or a chain of interdependent events exceed a figure, which surpasses the insurer's or the international insurance market's capabilities. The gradual nature of insurability is evident in this case, since insurability rests solely on the size of the potential damages. Especially natural catastrophes and nuclear risks approach these limits.

\section{Possible expansions of insurability}

Let's get down to our basic question: what means can be employed to expand the limits of insurability and meet demand for insurance in society's interest, where risks currently remain uncovered? First it has to be examined how the conditions for marketable insurance should be organized. If this fails, we have to examine, whether the positive effects of insurance can be realized at least partially in similar institutions, especially with government support.

First and foremost, the insurance company's possibilities in product design and risk management deserve mention. Above all, the insurance products design is one approach, as discussed above. An insured risk can be interpreted as the intersection of the external risk, which the insured faces (possible events and subsequent losses), and the coverage defined in the policy. So the insurer may exclude those events or losses, which appear to him to exceed the limits of insurability, from the coverage. Or he can cover them only partially, that is employ e.g. some form of deductible, or assume the risk up to a predetermined limit. Partial coverage is most certainly an improvement on no coverage at all. Deductibles create an additional benefit by favorably influencing moral hazard.

On the other hand, the insurer can impact the insured's original risk exposure in a favorable manner, at least to a certain degree. This can be done either directly or indirectly through the policy's content (e.g. agreement to appropriate obligations or warranties). This case concerns all measures of risk management, especially and obviously loss prevention. There are numerous examples from the recent past, above all in the insurance of environmental liabilities, that only intense risk control and loss prevention allow a risk to be insured. Planned procurement of information about the risk situation generally reduces the frequently extreme diagnostic risk. On occasion, direct risk supervision can reduce dangerous asymmetric information and contain moral hazard and adverse selection.

An example may clarify existing difficulties in the definition of insurance products. In the insurance of environmental liabilities so-called "gradual damages" are disputed. In contrast to "sudden and accidental" disruptive events, these are widely considered to exceed the limits of insurability. Since the German legislation on environmental liability (Gesetz über die Umwelthaftung vom 10.12.1990) doesn't exclude such damages from an individual's liability, German insurers have included them in their coverage with cautiously worded limitations. ${ }^{7}$ The insurers now face the problem, that they can't find

7 For details concerning German environmental liability law and environmental liability insurance in Germany see e.g. Schmidt-Salzer (1992) and Schmidt-Salzer/Schramm (1993). For analyses of insurability of environmental liability see e.g. Kleindorfer (1987), Kunreuther (1987), Abraham (1980), Endres/Schwarze (1992), Karten (1996). 
sufficient reinsurance in the world market, because its participants hold a different view of insurability. From risk theory's point of view, suddenness is irrelevant; interesting is whether the event is random, e.g. whether it can be foreseen or not.

The German model is an attempt to increase the number of insurable events through appropriate coverage by laying down exactly defined and restricted compensations, which as a rule deserves a warm welcome. The difficulty posed by gradual damages lies not so much in the question of whether they were random than in the fact of their long latency and the resulting problem of unambiguously allocating them to a specific coverage.

As far as I've been able to discern, insurer's internal risk management of the insured portfolio also provides widely unexhausted possibilities to expand capacity. A systematic optimization of reinsurance programs, which principally should address the entire company and not merely individual business lines, promises to enhance the insurer's flexibility.

Supplying sufficient security reserves within an insurer's internal risk management deserves special attention; if the stabilizing of risks in the insurance collective reaches a boundary, regardless whether the cause is that, the individual risks are too large, significant chain reactions can come to bear, or that the diagnostic risk is especially grave. Thus, the stabilizing of risks over time always gains in importance in such situations. Stabilizing over time requires, however, that sufficient security reserves can be accessed. Capital markets can supply such reserves or they can also be financed by safety loading in the premium. Both the costs and limitations of these financing methods are considerable. Creating special reserves, such as the German "fluctuation reserve" (Schwankungsrückstellung $)^{8}$, constitutes a suitable instrument for combatting risks with long-term fluctuations in their amount of damages over time. Measures of this kind don't enjoy much latitude: they're exposed to the market's pressures and the tax authority's mistrust.

In light of this comment, it's quite apparent, that if government would like difficult risks to be insured, it can create favorable legal conditions to this end, for example, by granting tax relief to such special reserves.

Variable i.e. loss dependent premiums offer vast opportunities to share the burden of a risk with the insured. This entails a partial transfer of the original risk back to the insured, in that the premiums automatically align with the level of losses in the insurance collective or with the specific loss experience of group or individual policies. The latter case is termed experience rating. The insurer obtains a great deal of flexibility to adapt to changing risks through this measure. Experience rating is also appropriate, if agreeing to a fixed premium seems to be too dangerous to the insurer due to substantial diagnostic risk.

Any loss dependent premium always contains elements of a deductible (i.e. partial self insurance) and offers incentives to counteract moral hazard. Even the creation of captives or the so-called "captive accounting" leads to similar effects, as do all other forms of coverage in the so-called "alternative insurance market." All alternative forms for

\footnotetext{
${ }^{8}$ See Karten (1980).
} 
financing risk can be traced back to some form of deductible or to a transfer of risk back to the threatened individuals and companies by some kind of variable premiums. The variety of new risk financing constructions and melodious names for them seems to know no boundaries. However, even if a complete retransfer of collective risk back to the insured, as it was done in historic mutuals, seems possible, there's no guarantee, that the problem of insurability can be easily solved, because in extreme cases, e.g. the risk of war, no one would be prepared, to accept a similar allocation procedure.

The creation of dependable legal conditions must be demanded from the legislative and judicature, so that insurers won't be overwhelmed in terms of risks' unambiguity. Yet this very matter leads me to an especially sceptical stance in light of the apparently unrestricted expansion and intensification of liability rules. I doubt, that any single insurer or association will ever succeed in wording covenauts, that withstand before a USAmerican jury.

Finally, the insurance market should be open to new insurers, especially in the form of mutual risk compensation. The history of insurance has shown, that at the same time, that the well-established insurers in the market no longer deem themselves capable of covering difficult risks, self-help organizations formed by the concerned parties come in and cover the risks as mutuals or broad captives. The so-called "bedpan mutuals", which cover US-American medical liability risks are an example. Favorable conditions for organizations of this sort should also be developed.

If the insurance supply in the market does not suffice to preserve society's interests in the end, then mixed systems should be considered. In this instance, the principle should be followed, that government or other organizations garner the greatest advantages possible from the insurers' professional and organizational know how and that they try to maintain the greatest number of insurance's positive effects possible. Even then, risks should be allocated among economic subjects as well as possible according to their cause. Over that the state should foster all preventive effects. This occurs for the most part, for example, when the state functions only as a reinsurer to cover losses from extreme natural catastrophes and thus solves the problem of insufficient capacity.

It's also conceivable - one of the author's favorite ideas - that insurers make use of the capacity of other economic subjects (large industrial companies, banks, etc.) to bear risk, in that they employ such non-insurers as reinsurers or coinsurers with a respective share of the risk concerned. Analogous to the system of leader and follower in Lloyds' London market, the successive risk bearer could get involved without any special know how, by trusting the leading insurer. The initial attempts to spread reinsurance risks through the Chicago Board of Trade with so-called "insurance futures" deserve mention in this connection, although they haven't yet met with great success.

Between the extremes of pure insurance and leaving individuals facing uncovered risks to fend for themselves, other models as intermediate solutions are conceivable: for example, gradiated and coordinated systems of liability and coverage, as in Germany's nuclear legislation, state support of insurance pools, or the stipulation of public compensation systems, for which insurers only provide organizational support. 
Before ending, we come to the conclusion, that insurance's technical possibilities to achieve risk compensation have yet to be exhausted, but also that, all the same, the limits of insurability cannot be expanded at will.

We have not addressed functionally mixed systems, which - such as social insurance combine other political goals with risk spreading, such as social redistribution or other tasks of economic policy. In terms of insurability, they must be viewed with extreme caution and scepticism. In a functioning market, they act as substantial disturbances, because they reduce the allocation of risk's costs to economic agents according to their cause, can inhibit preventive measures, and lead to misallocation in other areas. Then again, that's another topic in itself.

\section{REFERENCES}

ABRAHAM, Kenneth S. (1980): "Environmental Liability and the Limits of Insurance", Columbia Law Review 88, pp. 942-988.

ENDRES, Alfred and SCHWARZE Reimund (1992): "Gibt es Grenzen der Versicherbarkeit von Umweltrisiken?, in: A. Endres, E. Rehbinder, R. Schwarze" (eds.): Haftung und Versicherung für Umweltschäden aus ökonomischer und juristischer Sicht, Berlin, Heidelberg, pp. 83-119.

FAURE, Michael G. (1995): "The Limits to Insurability from a Law and Economics Perspective", The Geneva Papers on Risk and Insurance 20, pp. 454-462.

KARTEN, Walter (1972): Zum Problem der Versicherbarkeit und zur Risikopolitik des Versicherungsunternehmens - betriebswirtschaftliche Aspekte, Zeitschrift für die gesamte Versicherungswissenschaft 61, pp. 279-299.

KARTEN, Walter (1980): The New "Schwankungsrückstellung" in Annual Statements of German Insurers, The Geneva Papers on Risk and Insurance 17, pp. 54-62.

KARTEN, Walter (1988): "Existenzrisiken der Gesellschaft - Herausforderung für Assekuranz", Zeitschrift für die gesamte Versicherungswissenschaft 77, pp. 343-362.

KARTEN, Walter (1993): "Das Einzelrisiko und seine Kalkulation”, Versicherungswirtschaftliches Studienwerk, Studientext 12, Wiesbaden.

KARTEN, Walter with RICHTER Andreas (1996): “Aspekte von Versicherbarkeit und Produktgestaltung am Beispiel der Umwelthaftpflichtversicherung, in: J. Mugler, M. Nitsche (eds.): Versicherung, Risiko und Internationalisierung - Herausforderungen für Unternehmensführung und Politik"; Festschrift für Heinrich Stremitzer zum 60. Geburtstag, Wien, pp. 17-30.

KLEINDORFER, Paul R. (1987): "Die Umweltschaden-Haftpflicht-Versicherung: Ein Ausblick auf die Krise in der US-Versicherungswirtschaft", Zeitschrift für die gesamte Versicherungswissenschaft 76, pp. 1-23.

KUNREUTHER, Howard (1987): "Problems and Issues of Environmental Liability Insurance", The Geneva Papers on Risk and Insurance 12, pp. 180-197.

SCHMIDT-SALZER, Joachim (1992): "Kommentar zum Umwelthaftungsrecht", betriebliche Risiken und innerbetriebliche Verantwortung, Heidelberg.

SCHMIDT-SALZER, Joachim and SCHRAMM Stephan (1993): Kommentar zur Umwelthaftpflichtversicherung. Das Umwelthaftpflicht-Modell '92 des HUK-Verbandes, Heidelberg.

SINN, Hans-Werner (1988): "Gedanken zur volkswirtschaftlichen Bedeutung des Versicherungswesens", Zeitschrift für die gesamte Versicherungswissenschaft 77, pp. 1-27. 